\title{
Crystallographic Insights into Uranyl Sulfate Minerals Formation: Synthesis and Crystal Structures of Three Novel Cesium Uranyl Sulfates
}

\author{
Olga S. Tyumentseva ${ }^{1}$, Ilya V. Kornyakov ${ }^{1,2}{ }^{\oplus}$, Sergey N. Britvin ${ }^{1,2}{ }^{(D}$, Andrey A. Zolotarev ${ }^{1}(\mathbb{D}$ \\ and Vladislav V. Gurzhiy ${ }^{1, *(\mathbb{D})}$ \\ 1 Department of Crystallography, Institute of Earth Sciences, St. Petersburg State University, University Emb. \\ 7/9, St. 199034 Petersburg, Russian; o-tyumentseva@mail.ru (O.S.T.); ikornyakov@mail.ru (I.V.K.); \\ sbritvin@gmail.com (S.N.B.); a.zolotarev@spbu.ru or aazolotarev@gmail.com (A.A.Z.) \\ 2 Kola Science Centre, Russian Academy of Sciences, Fersmana 14, 184209 Apatity, Russia \\ * Correspondence: vladislav.gurzhiy@spbu.ru or vladgeo17@mail.ru
}

Received: 16 November 2019; Accepted: 5 December 2019; Published: 9 December 2019 updates

\begin{abstract}
An alteration of the uranyl oxide hydroxy-hydrate mineral schoepite $\left[\left(\mathrm{UO}_{2}\right)_{8} \mathrm{O}_{2}(\mathrm{OH})_{12}\right]$ $\left(\mathrm{H}_{2} \mathrm{O}\right)_{12}$ at mild hydrothermal conditions was studied. As the result, four different crystalline phases $\mathrm{Cs}\left[\left(\mathrm{UO}_{2}\right)\left(\mathrm{SO}_{4}\right)(\mathrm{OH})\right]\left(\mathrm{H}_{2} \mathrm{O}\right)_{0.25}(\mathbf{1}), \mathrm{Cs}_{3}\left[\left(\mathrm{UO}_{2}\right)_{4}\left(\mathrm{SO}_{4}\right)_{2} \mathrm{O}_{3}(\mathrm{OH})\right]\left(\mathrm{H}_{2} \mathrm{O}\right)_{3}(2), \mathrm{Cs}_{6}\left[\left(\mathrm{UO}_{2}\right)_{2}\left(\mathrm{SO}_{4}\right)_{5}\right]\left(\mathrm{H}_{2} \mathrm{O}\right)_{3}$ (3), and $\mathrm{Cs}_{2}\left[\left(\mathrm{UO}_{2}\right)\left(\mathrm{SO}_{4}\right)_{2}\right]$ (4) were obtained, including three novel compounds. The obtained $\mathrm{Cs}$ uranyl sulfate compounds 1, 3, and 4 were analyzed using single-crystal XRD, EDX, as well as topological analysis and information-based structural complexity measures. The crystal structure of 3 was based on the 1D complex, the topology of which was unprecedented for the structural chemistry of inorganic oxysalts. Crystal chemical analysis performed herein suggested that the majority of the uranyl sulfates minerals were grown from heated solutions, and the temperature range could be assumed from the manner of interpolyhedral linkage. The presence of edge-sharing uranyl bipyramids most likely pointed to the temperatures of higher than $100{ }^{\circ} \mathrm{C}$. The linkage of sulfate tetrahedra with uranyl polyhedra through the common edges involved elevated temperatures but of lower values $\left(\sim 70-100{ }^{\circ} \mathrm{C}\right)$. Complexity parameters of the synthetic compounds were generally lower than that of uranyl sulfate minerals, whose structures were based on the complexes with the same or genetically similar topologies. The topological complexity of the uranyl sulfate structural units contributed the major portion to the overall complexity of the synthesized compounds, while the complexity of the respective minerals was largely governed by the interstitial structure and H-bonding system.
\end{abstract}

Keywords: uranyl; hydroxy-hydrate; sulfate; cesium; schoepite; crystal structure; topology; structural complexity

\section{Introduction}

Uranyl-oxide hydroxy-hydrate minerals are regarded to be the products of the first stages of uraninite alteration under oxidizing conditions [1-5]. Being formed as the result of the reaction of bedrock with aqueous fluids, these natural compounds obviously play an important, if not a key, role in the uranium transfer to the environment. In addition, uranyl-oxide hydroxy-hydrate phases can be regarded as the precursors of the formation of other secondary uranium-bearing minerals, under reaction with waters enriched by various cations (usually mono- and divalent) and oxyanions $\left(\mathrm{CO}_{3}{ }^{2-}\right.$, $\mathrm{SO}_{4}{ }^{2-}, \mathrm{PO}_{4}{ }^{2-}$, etc.). The description of the new mineral species is rarely followed by the experiments, which could shed some light on the conditions of their genesis. Due to the complexity of uranyl-bearing 
complexes forming in aqueous solutions in the presence of a certain cation/oxyanion combination as a function of $\mathrm{pH}$, the exact formation mechanisms of uranyl minerals are not fully understood. In this study, we presented the results of uranyl sulfate synthesis experiments that might elucidate some of the formation behavior of natural uranyl sulfates.

Herein, we reported on the alteration experiment of the synthetic analog of uranyl-oxide hydroxy-hydrate mineral schoepite, $\left[\left(\mathrm{UO}_{2}\right)_{8} \mathrm{O}_{2}(\mathrm{OH})_{12}\right]\left(\mathrm{H}_{2} \mathrm{O}\right)_{12}[6,7]$. As the result, four different crystalline phases $\mathrm{Cs}\left[\left(\mathrm{UO}_{2}\right)\left(\mathrm{SO}_{4}\right)(\mathrm{OH})\right]\left(\mathrm{H}_{2} \mathrm{O}\right)_{0.25}(\mathbf{1}), \mathrm{Cs}_{3}\left[\left(\mathrm{UO}_{2}\right)_{4}\left(\mathrm{SO}_{4}\right)_{2} \mathrm{O}_{3}(\mathrm{OH})\right]\left(\mathrm{H}_{2} \mathrm{O}\right)_{3}$ (2) [8], $\mathrm{Cs}_{6}\left[\left(\mathrm{UO}_{2}\right)_{2}\left(\mathrm{SO}_{4}\right)_{5}\right]$ $\left(\mathrm{H}_{2} \mathrm{O}\right)_{3}(3)$, and $\mathrm{Cs}_{2}\left[\left(\mathrm{UO}_{2}\right)\left(\mathrm{SO}_{4}\right)_{2}\right](4)$ were obtained, including three novel compounds. The obtained $\mathrm{Cs}$ uranyl sulfate compounds were analyzed using single-crystal X-ray diffraction (SC XRD), energy-dispersive $X$-ray analysis (EDX), as well as topological analysis and information-based structural complexity measures.

\section{Materials and Methods}

\subsection{Synthesis}

An analog of the hydroxy-hydrated uranyl oxide mineral schoepite $\left(\left[\left(\mathrm{UO}_{2}\right)_{8} \mathrm{O}_{2}(\mathrm{OH})_{12}\right]\left(\mathrm{H}_{2} \mathrm{O}\right)_{12}[6,7]\right)$ was synthesized according to the procedure discussed in [9], and its purity was checked using powder XRD; $\mathrm{H}_{2} \mathrm{SO}_{4}$ (Sigma-Aldrich, 98\%) and $\mathrm{Cs}_{2} \mathrm{SO}_{4}$ (Vekton, Russia, 99\%) were used as received. The $0.2 \mathrm{~g}$ of synthetic schoepite $(0.03 \mathrm{mmol}), 0.12 \mathrm{~g}$ of cesium sulfate $(0.33 \mathrm{mmol})$, and $0.01(0.19 \mathrm{mmol}) \mathrm{ml}$ of sulfuric acid were dissolved in $10 \mathrm{~mL}$ of deionized water. The solution was stirred and loaded in a $23 \mathrm{~mL}$ Teflon-lined steel autoclave, which was placed in a box furnace and heated to $110{ }^{\circ} \mathrm{C}$. After $24 \mathrm{~h}$, the furnace was cooled at $\sim 20^{\circ} \mathrm{C} / \mathrm{h}$ to room temperature. A fine crystalline precipitate covered by a translucent light-yellow solution was found at the bottom of the Teflon capsule. Afterward, the product was poured into a watch glass. The detailed examination under the optical microscope revealed the presence of two types of crystals (Figure 1): The bulk of the precipitant was tiny yellowish isometric crystals with nearly diamond luster (compound 1), interspersed with larger in size, but of much worse quality orange rhombus lamina crystals (compound 2). After picking several crystals for further diagnostics, the product was left in a watch glass to evaporate at room temperature. In a few days, two more kinds of crystals were detected in a small amount at the edge of the solution (Figure 1): green rosettes of thin plates (compound 3) and light green flattened rhombic crystals (compound 4).

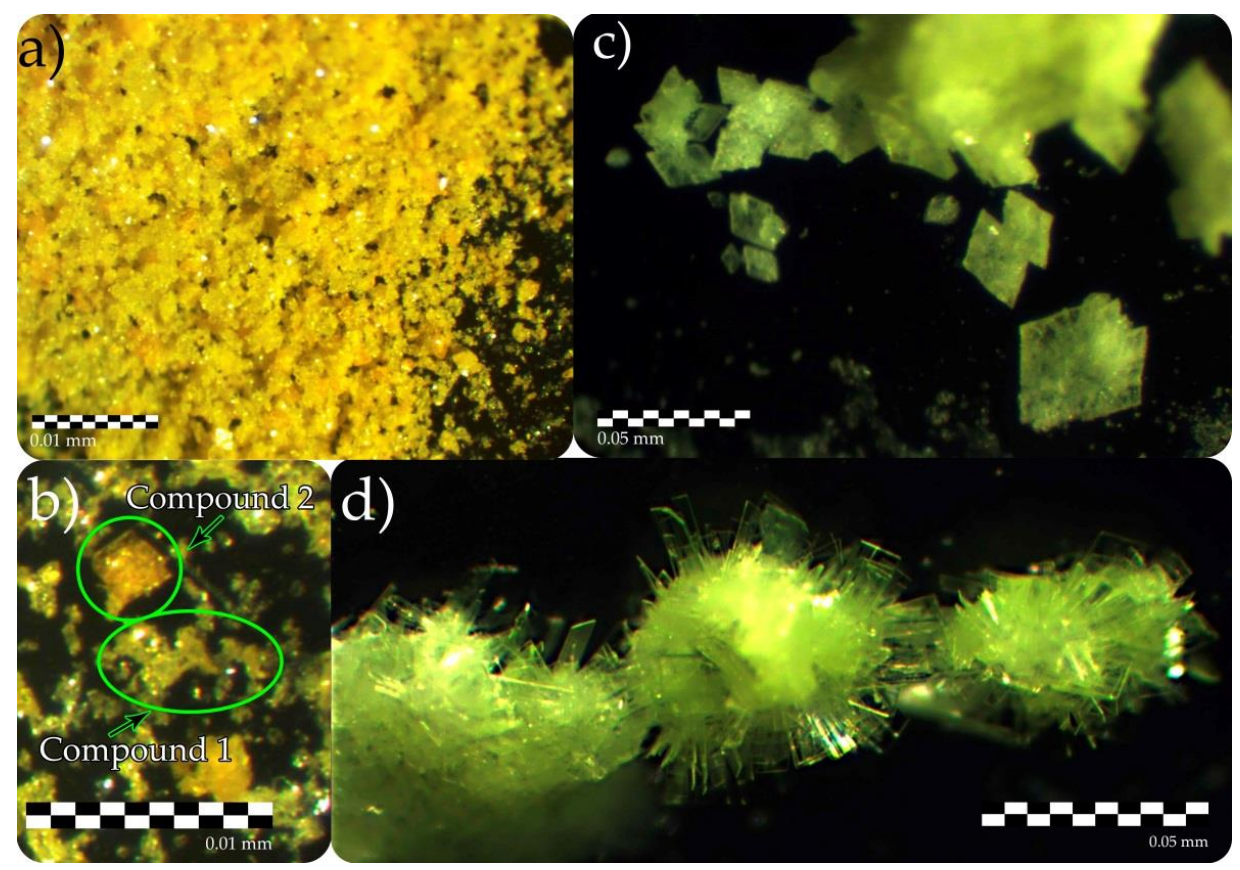

Figure 1. Crystals of $\mathbf{1}(\mathbf{a}, \mathbf{b}), \mathbf{2}(\mathbf{a}, \mathbf{b}), \mathbf{3}$ (c) and $\mathbf{4}(\mathrm{d})$ formed in the described synthetic experiment. 


\subsection{Chemical Analysis}

Small pieces of single crystals of $\mathbf{1 - 4}$ verified on the diffractometer were crushed, pelletized, and carbon-coated. The chemical composition of the samples was determined using a TM 3000 scanning electron microscope equipped with an Oxford EDX spectrometer, with an acquisition time of $15 \mathrm{~s}$ per point in energy-dispersive mode (acceleration voltage $15 \mathrm{kV}$ ). The following analytical standards were used: $\mathrm{CsBr}(\mathrm{CsK})$, barite (SK), and $\mathrm{U}_{3} \mathrm{O}_{8}(\mathrm{UK})$.

Analytical calculations. Compound 1: atomic ratio from structural data Cs 1.00, U 1.00, S 1.00; found by EDX: Cs 1.03, U 1.05, S 0.92. Compound 2: atomic ratio from structural data Cs 3.00, U 4.00, S 2.00; found by EDX: Cs 2.93, U 4.06, S 2.01. Compound 3: atomic ratio from structural data Cs 6.00, U 2.00, S 5.00; found by EDX: Cs 5.96, U 2.07, S 4.97. Compound 4: atomic ratio from structural data Cs 2.00, U 1.00, S 2.00; found by EDX: Cs 1.95, U 1.05, S 2.00.

\subsection{Single-Crystal X-Ray Diffraction Study}

Single crystals of 1-4 were selected under binocular, coated in oil-based cryoprotectant, and mounted on cryoloops. Diffraction data were collected using a Bruker Kappa Duo diffractometer (Bruker AXS, Madison, WI, USA) equipped with a CCD (charge-coupled device) Apex II detector operated with monochromated microfocused MoK $\alpha$ radiation $(\lambda[\mathrm{MoK} \alpha]=0.71073 \AA)$ at $45 \mathrm{kV}$ and $0.6 \mathrm{~mA}$. Diffraction data were collected at room temperature with frame widths of $0.5^{\circ}$ in $\omega$ and $\varphi$, and exposures of 40 to $120 \mathrm{~s}$ per frame. Diffraction data were integrated and corrected for polarization, background, and Lorentz effects. An empirical absorption correction based on spherical harmonics implemented in the SCALE3 ABSPACK algorithm was applied in the CrysAlisPro program [10]. The unit-cell parameters (Table 1) were refined using the least-squares techniques. The structure was solved by a dual-space algorithm and refined using the SHELX programs $[11,12]$ incorporated in the OLEX2 program package [13]. The final models include coordinates and anisotropic displacement parameters for all non- $\mathrm{H}$ atoms. The $\mathrm{H}$ atoms of $\mathrm{OH}$ groups and $\mathrm{H}_{2} \mathrm{O}$ molecules were localized from difference Fourier maps and were included in the refinement with $U_{\text {iso }}(\mathrm{H})$ set to $1.5 U_{\text {eq }}(\mathrm{O})$ and $\mathrm{O}-\mathrm{H}$ bond-length restraints to $0.95 \AA$. Selected bond lengths and angles are listed in Tables 2-4. Checking of the unit-cell parameters along with the results of the chemical analyses showed that the crystals of 2 were the cesium uranyl sulfate phase, which was reported previously [8]. Due to the small size and low quality of the crystals of 3 , refinement parameters were rather high, but the structural model was quite reliable.

Table 1. Crystallographic data for 1,3 , and 4 .

\begin{tabular}{|c|c|c|c|}
\hline Compound & 1 & 3 & 4 \\
\hline Crystal System & Orthorhombic & Triclinic & Monoclinic \\
\hline$a(\AA)$ & $9.2021(3)$ & $7.5829(3)$ & $10.8351(5)$ \\
\hline$b(\AA)$ & $13.2434(5)$ & 14.4441(11) & $9.0317(5)$ \\
\hline$c(\AA)$ & $12.5610(3)$ & $14.6458(14)$ & $11.8494(6)$ \\
\hline$\alpha\left(^{\circ}\right)$ & 90 & $93.737(7)$ & 90 \\
\hline$\beta\left(^{\circ}\right)$ & 90 & $99.535(5)$ & $110.7510(10)$ \\
\hline$\gamma\left({ }^{\circ}\right)$ & 90 & $99.614(5)$ & 90 \\
\hline$V\left(\AA^{3}\right)$ & $1530.77(8)$ & $1552.6(2)$ & 1084.35(10) \\
\hline Molecular weight & 520.51 & 1871.87 & 727.97 \\
\hline Space group & Pnma & $P-1$ & $P 2_{1} / n$ \\
\hline$\mu\left(\mathrm{mm}^{-1}\right)$ & 26.156 & 17.779 & 22.004 \\
\hline Temperature (K) & & 293(2) & \\
\hline Z & 8 & 2 & 4 \\
\hline$D_{\text {calc }}\left(\mathrm{g} / \mathrm{cm}^{3}\right)$ & 4.517 & 4.004 & 4.459 \\
\hline Crystal size $\left(\mathrm{mm}^{3}\right)$ & $0.06 \times 0.04 \times 0.02$ & $0.04 \times 0.03 \times 0.005$ & $0.08 \times 0.05 \times 0.02$ \\
\hline Diffractometer & & Bruker Kappa Apex II Duo & \\
\hline Radiation & & $\operatorname{MoK} \alpha$ & \\
\hline
\end{tabular}


Table 1. Cont.

\begin{tabular}{cccc}
\hline Compound & $\mathbf{1}$ & $\mathbf{3}$ & $\mathbf{4}$ \\
\hline Total reflections & 13617 & 8814 & 27773 \\
Unique reflections & 1824 & 5151 & 2493 \\
Angle range $2 \theta\left(^{\circ}\right)$ & $4.47-55.00$ & $3.84-50.00$ & $4.38-55.00$ \\
Reflections with $\left|F_{\mathrm{o}}\right| \geq 4 \sigma_{F}$ & 1560 & 3806 & 2308 \\
$R_{\text {int }}$ & 0.0503 & 0.0784 & 0.0358 \\
$R_{\sigma}$ & 0.0201 & 0.0949 & 0.0154 \\
$R_{1}\left(\left|F_{\mathrm{o}}\right| \geq 4 \sigma_{F}\right)$ & 0.0261 & 0.0829 & 0.0131 \\
$w R_{2}\left(\left|F_{\mathrm{o}}\right| \geq 4 \sigma_{F}\right)$ & 0.0607 & 0.2050 & 0.0278 \\
$R_{1}($ all data $)$ & 0.0336 & 0.1077 & 0.0157 \\
$w R_{2}($ all data $)$ & 0.0648 & 0.2215 & 0.0287 \\
$S$ & 1.054 & 1.068 & 1.040 \\
$\rho_{\min }, \rho_{\max }, e / \AA^{3}$ & $-1.097,2.145$ & $-4.179,3.819$ & $-0.604,0.692$ \\
$\mathrm{CSD}$ & 1965819 & 1965817 & 1965818 \\
\hline$R_{1}=\Sigma|| F_{\mathrm{o}}|-| F_{\mathrm{c}} \| / \Sigma\left|F_{\mathrm{o}}\right| ; w R_{2}=\left\{\Sigma\left[w\left(F_{\mathrm{o}}{ }^{2}-F_{\mathrm{c}}{ }^{2}\right)^{2}\right] / \Sigma\left[w\left(F_{\mathrm{o}}{ }^{2}\right)^{2}\right]\right\}^{1 / 2} ; w=1 /\left[\sigma^{2}\left(F_{\mathrm{o}}{ }^{2}\right)+(\mathrm{a} P)^{2}+\mathrm{b} P\right]$, where $P=\left(F_{\mathrm{o}}{ }^{2}+2 F_{\mathrm{c}}{ }^{2}\right) / 3 ;$ \\
$s=\left\{\Sigma\left[w\left(F_{\mathrm{o}}{ }^{2}-F_{\mathrm{c}}{ }^{2}\right)\right] /(n-p)\right\}^{1 / 2}$ where $n$ is the number of reflections, and $p$ is the number of refinement parameters.
\end{tabular}

Table 2. Selected bond lengths $(\AA)$ and angles $\left({ }^{\circ}\right)$ in the structure of $\mathbf{1}$.

\begin{tabular}{|c|c|c|c|}
\hline Bond & & Bond & \\
\hline U1-O1 & $1.768(5)$ & S1-O6 & $1.481(5)$ \\
\hline $\mathrm{U} 1-\mathrm{O} 2$ & $1.768(5)$ & S1-O7 & $1.426(6)$ \\
\hline$<\mathrm{U} 1-\mathrm{O}_{U r}>$ & 1.768 & $<\mathrm{S} 1-\mathrm{O}>$ & 1.465 \\
\hline U1-O3 & $2.351(4)$ & & \\
\hline $\mathrm{U} 1-\mathrm{OH} 4$ & $2.330(5)$ & $<\mathrm{Cs} 1-\mathrm{O}>\mathrm{CN}^{*}=8$ & 3.313 \\
\hline $\mathrm{U} 1-\mathrm{OH} 4$ & $2.322(5)$ & $<\mathrm{Cs} 2-\mathrm{O}>\mathrm{CN}^{*}=10$ & 3.302 \\
\hline U1-O5 & $2.421(5)$ & & \\
\hline U1-O6 & $2.358(5)$ & Angle & \\
\hline \multirow[t]{2}{*}{$<\mathrm{U} 1-\mathrm{O}_{e q}>$} & 2.356 & U1-O4-U1 & $113.0(2)$ \\
\hline & & S1-O5-U1 & 140.3(3) \\
\hline $\mathrm{S} 1-\mathrm{O} 3$ & $1.478(4)$ & S1-O6-U1 & $140.3(3)$ \\
\hline S1-O5 & $1.473(5)$ & & \\
\hline
\end{tabular}

*-Coordination numbers $(\mathrm{CN})$ at the $3.6 \AA$ limit, for the average bond length value.

Table 3. Selected bond lengths $(\AA)$ and angles $\left(^{\circ}\right)$ in the structure of 3 .

\begin{tabular}{cccc}
\hline Bond & \multicolumn{3}{c}{ Bond } \\
\hline $\mathrm{U} 1-\mathrm{O} 1$ & $1.770(19)$ & $\mathrm{S} 3-\mathrm{O} 14$ & $1.50(2)$ \\
$\mathrm{U} 1-\mathrm{O} 2$ & $1.80(2)$ & $<\mathrm{S} 3-\mathrm{O}>$ & 1.47 \\
$<\mathrm{U} 1-\mathrm{O}{ }_{\mathrm{U}}>$ & 1.785 & & \\
$\mathrm{U} 1-\mathrm{O} 3$ & $2.336(19)$ & $\mathrm{S} 4-\mathrm{O} 17$ & $1.51(2)$ \\
$\mathrm{U} 1-\mathrm{O} 4$ & $2.40(2)$ & $\mathrm{S} 4-\mathrm{O} 18$ & $1.48(2)$ \\
$\mathrm{U} 1-\mathrm{O} 5$ & $2.428(17)$ & $\mathrm{S} 4-\mathrm{O} 19$ & $1.43(2)$ \\
$\mathrm{U} 1-\mathrm{O} 6$ & $2.347(19)$ & $\mathrm{S} 4-\mathrm{O} 20$ & $1.42(3)$ \\
$\mathrm{U} 1-\mathrm{O} 7$ & $2.35(2)$ & $<\mathrm{S} 4-\mathrm{O}>$ & 1.46 \\
$<\mathrm{U} 1-\mathrm{O}_{e q}>$ & 2.37 & & \\
& & $\mathrm{~S} 5-\mathrm{O} 21$ & $1.48(3)$ \\
$\mathrm{U} 2-\mathrm{O} 15$ & $1.76(2)$ & $\mathrm{S} 5-\mathrm{O} 22$ & $1.43(3)$ \\
$\mathrm{U} 2-\mathrm{O} 16$ & $1.77(2)$ & $\mathrm{S} 5-\mathrm{O} 23$ & $1.46(3)$ \\
$<\mathrm{U} 2-\mathrm{O}$ Ur & 1.765 & $\mathrm{~S} 5-\mathrm{O} 24$ & $1.43(3)$ \\
$\mathrm{U} 2-\mathrm{O} 14$ & $2.349(19)$ & $<\mathrm{S} 5-\mathrm{O}>$ & 1.45 \\
$\mathrm{U} 2-\mathrm{O} 17$ & $2.42(2)$ & & \\
$\mathrm{U} 2-\mathrm{O} 21$ & $2.35(3)$ & $<\mathrm{Cs} 1-\mathrm{O}>\mathrm{CN}{ }^{*}=12$ & 3.26 \\
$\mathrm{U} 2-\mathrm{O} 22$ & $2.38(3)$ & $<\mathrm{Cs} 2-\mathrm{O}>\mathrm{CN}{ }^{*}=10$ & 3.32 \\
\hline
\end{tabular}


Table 3. Cont.

\begin{tabular}{|c|c|c|c|}
\hline Bond & & Bond & \\
\hline $\mathrm{U} 2-\mathrm{O} 22 \mathrm{~A}$ & $2.26(10)$ & $<\mathrm{Cs} 3-\mathrm{O}>\mathrm{CN}^{*}=9$ & 3.33 \\
\hline \multirow[t]{2}{*}{$<\mathrm{U} 2-\mathrm{O}_{e q}>$} & 2.35 & $<\mathrm{Cs} 4-\mathrm{O}>\mathrm{CN}^{*}=10$ & 3.33 \\
\hline & & $<\mathrm{Cs} 5-\mathrm{O}>\mathrm{CN}^{*}=9$ & 3.27 \\
\hline $\mathrm{S} 1-\mathrm{O} 3$ & $1.492(19)$ & $<\mathrm{Cs} 6-\mathrm{O}>\mathrm{CN}^{*}=10$ & 3.28 \\
\hline S1-O7 & $1.50(2)$ & & \\
\hline $\mathrm{S} 1-\mathrm{O} 8$ & $1.42(2)$ & Angle & \\
\hline S1-O9 & $1.43(3)$ & U1-O3-S1 & $138.4(13)$ \\
\hline \multirow[t]{2}{*}{$<\mathrm{S} 1-\mathrm{O}>$} & 1.46 & U1-O4-S2 & $100.9(9)$ \\
\hline & & U1-O5-S2 & 99.6(9) \\
\hline $\mathrm{S} 2-\mathrm{O} 4$ & $1.505(19)$ & U1-O6-S3 & $141.8(12)$ \\
\hline S2-O5 & $1.510(19)$ & U1-O7-S1 & $140.0(14)$ \\
\hline S2-O10 & $1.42(2)$ & U2-O14-S3 & $135.7(12)$ \\
\hline S2-O11 & $1.42(2)$ & U2-O17-S4 & $100.5(10)$ \\
\hline \multirow{2}{*}{$<\mathrm{S} 2-\mathrm{O}>$} & 1.46 & U2-O18-S4 & $101.3(11)$ \\
\hline & & U2-O21-S5 & $146.0(16)$ \\
\hline S3-O6 & $1.497(19)$ & U2-O22-S5 & $146(2)$ \\
\hline S3-O12 & $1.494(19)$ & $\mathrm{U} 2-\mathrm{O} 22 \mathrm{~A}-\mathrm{S} 5$ & 157(7) \\
\hline S3-O13 & $1.39(2)$ & & \\
\hline
\end{tabular}

*-Coordination numbers $(\mathrm{CN})$ at the $3.6 \AA$ limit, for the average bond length value.

Table 4. Selected bond lengths $(\AA)$ and angles $\left({ }^{\circ}\right)$ in the structure of 4 .

\begin{tabular}{cccc}
\hline Bond & \multicolumn{3}{c}{ Bond } \\
\hline $\mathrm{U} 1-\mathrm{O} 1$ & $1.775(2)$ & $\mathrm{S} 2-\mathrm{O} 7$ & $1.477(2)$ \\
$\mathrm{U} 1-\mathrm{O} 2$ & $1.768(2)$ & $\mathrm{S} 2-\mathrm{O} 8$ & $1.430(3)$ \\
$\mathrm{U} 1-\mathrm{O}$ Ur & 1.772 & $\mathrm{~S} 2-\mathrm{O} 9$ & $1.486(2)$ \\
$\mathrm{U} 1-\mathrm{O} 4$ & $2.301(2)$ & $\mathrm{S} 2-\mathrm{O} 10$ & $1.492(2)$ \\
$\mathrm{U} 1-\mathrm{O} 5$ & $2.319(2)$ & $<\mathrm{S} 2-\mathrm{O}>$ & 1.471 \\
$\mathrm{U} 1-\mathrm{O} 7$ & $2.322(2)$ & & \\
$\mathrm{U} 1-\mathrm{O} 9$ & $2.478(2)$ & $<\mathrm{Cs} 1-\mathrm{O}>\mathrm{CN}^{*}=10$ & 3.286 \\
$\mathrm{U} 1-\mathrm{O} 10$ & $2.482(2)$ & $<\mathrm{Cs} 2-\mathrm{O}>\mathrm{CN}^{*}=10$ & 3.311 \\
$\mathrm{U} 1-\mathrm{O} e q$ & 2.380 & & \\
\cline { 3 - 4 } & & Angle & \\
$\mathrm{S} 1-\mathrm{O} 3$ & $1.446(2)$ & $\mathrm{S} 1-\mathrm{O} 4-\mathrm{U} 1$ & $142.45(14)$ \\
$\mathrm{S} 1-\mathrm{O} 4$ & $1.502(2)$ & $\mathrm{S} 1-\mathrm{O}-\mathrm{U} 1$ & $133.36(14)$ \\
$\mathrm{S} 1-\mathrm{O} 5$ & $1.502(2)$ & $\mathrm{S} 2-\mathrm{O} 7-\mathrm{U} 1$ & $148.09(16)$ \\
$\mathrm{S} 1-\mathrm{O} 6$ & $1.440(2)$ & $\mathrm{S} 2-\mathrm{O}-\mathrm{U} 1$ & $99.54(11)$ \\
$<\mathrm{S} 1-\mathrm{O}>$ & 1.473 & $\mathrm{~S} 2-\mathrm{O} 10-\mathrm{U} 1$ & $99.22(11)$ \\
\hline
\end{tabular}

*-Coordination numbers $(\mathrm{CN})$ at the $3.6 \AA$ limit, for the average bond length value.

Supplementary crystallographic data (see online Supplementary Materials) for 1, 3, and 4 were deposited in the Inorganic Crystal Structure Database and could be obtained from Fachinformationszentrum Karlsruhe via https://www.ccdc.cam.ac.uk/structures/.

\section{Results}

\subsection{Structure Descriptions}

The crystal structure of 1 contained one crystallographically nonequivalent $\mathrm{U}^{6+}$ atom with two short $\mathrm{U}^{6+} \equiv \mathrm{O}^{2-}$ bonds $(1.768(5) \AA)$, forming nearly linear $\mathrm{UO}_{2}{ }^{2+}$ uranyl ion $(U r)$, which was coordinated by another five oxygen atoms $<\mathrm{U} 1-\mathrm{O}_{e q}>=2.356 \AA$ that were arranged in the equatorial plane of the $\mathrm{UO}_{7}$ pentagonal bipyramid. Three of those $\mathrm{O}_{e q}$ atoms belonged to sulfate tetrahedra, while the other two cis-O atoms made an edge shared with the neighbor pentagonal bipyramid, thus forming a dimer. In addition, both $\mathrm{O}$ atoms from the shared edge were protonated to form $\mathrm{OH}^{-}$groups. There was one 
crystallographically nonequivalent $\mathrm{S}^{6+}$ atom tetrahedrally coordinated by four $\mathrm{O}^{2-}$ atoms. $\mathrm{U}$ dimers and S-centered tetrahedra shared common vertices to form a layered $\left[\left(\mathrm{UO}_{2}\right)\left(\mathrm{SO}_{4}\right)(\mathrm{OH})\right]^{-}$complexes (Figure 2a). Being 3-connected, sulfate tetrahedra had the fourth non-shared vertex oriented either up or down relative to the plane of the layer, which gave rise to geometric isomerism with various orientations of the sulfate tetrahedra. To distinguish the isomers, their orientation matrices were assigned using symbols $\mathbf{u}(u p)$ and $\mathbf{d}\left(\right.$ down). There were two nonequivalent $\mathrm{Cs}^{+}$atoms in the structure of 1 , occupying special positions on a mirror plane and arranged in the interlayer space along with substantially vacant and disordered over two sites $\mathrm{H}_{2} \mathrm{O}$ molecule.

a)

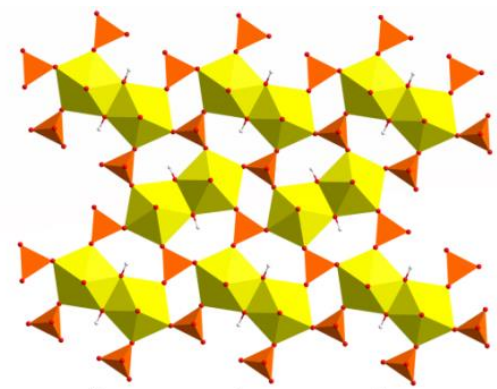

b)

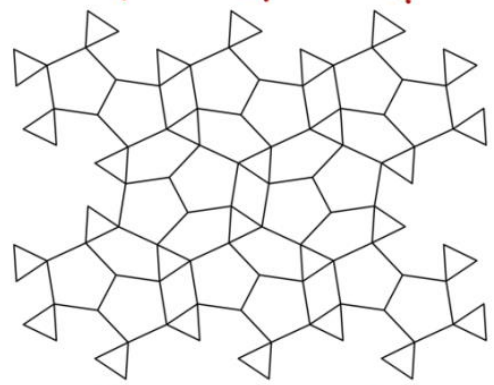

c)

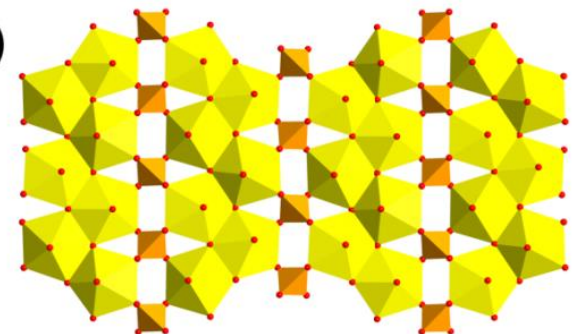

d)

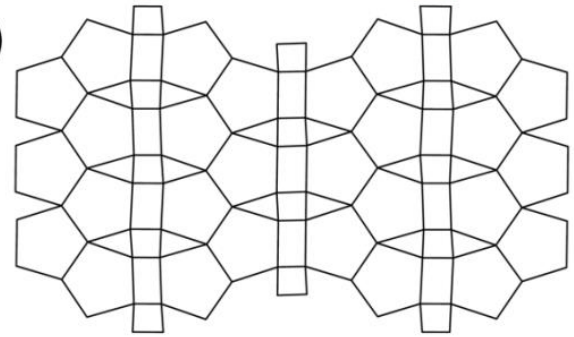

e)

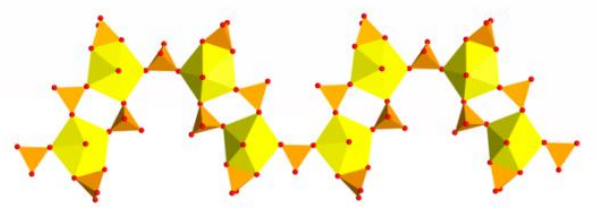

f)

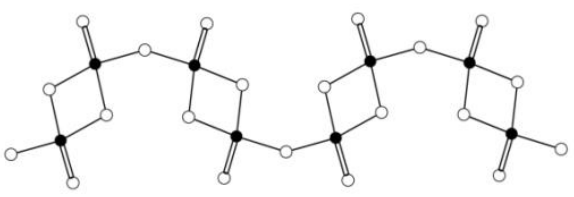

g)

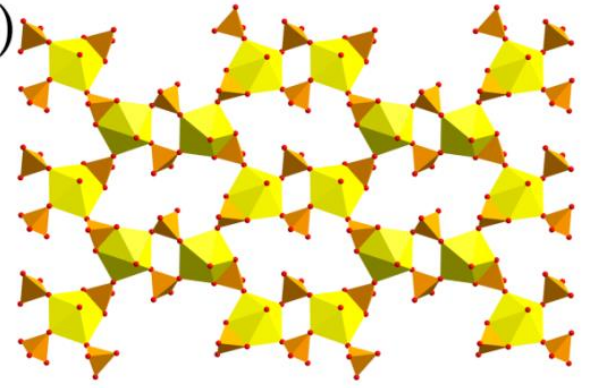

h)

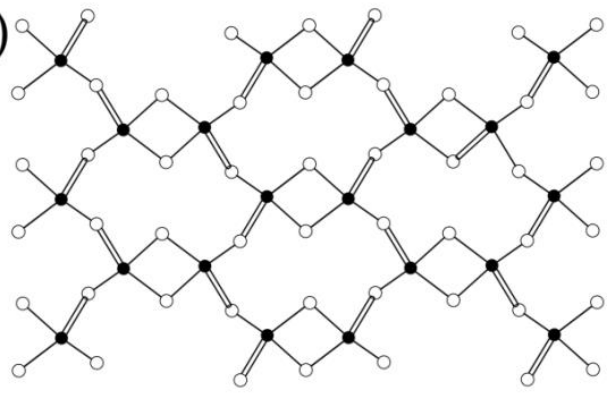

Figure 2. $1 \mathrm{D}$ and 2D complexes and their respective topologies in the structures of $\mathbf{1}(\mathbf{a}, \mathbf{b}), \mathbf{2}(\mathbf{c}, \mathbf{d}), \mathbf{3}(\mathbf{e}, \mathbf{f})$, and $4(\mathrm{~g}, \mathrm{~h})$. Legend: U-bearing coordination polyhedra = yellow; S-centered tetrahedra = orange; $\mathrm{O}$ atoms $=$ red; $\mathrm{H}$ atoms $=$ light grey; black nodes $=\mathrm{U}$ atoms, white nodes $=\mathrm{S}$ atoms .

There were two crystallographically nonequivalent $\mathrm{U}^{6+}$ atoms in the structure of $\mathbf{3}$ with two short $\mathrm{U}^{6+} \equiv \mathrm{O}^{2-}$ bonds (1.76(2)-1.80(2) $\AA$ ), forming $U r$. The $U r$ cations were coordinated by five oxygen atoms $<U r-\mathrm{O}_{e q}>=2.35$ and $2.37 \AA$ (for U1 and U2, respectively), which belonged to sulfate tetrahedra that were arranged in the equatorial plane of the $\mathrm{UO}_{7}$ pentagonal bipyramid. There were five $\mathrm{S}^{6+}$ atoms in the structure of 3, tetrahedrally coordinated by four $\mathrm{O}^{2-}$ atoms each. All sulfate tetrahedra were 2-connected, having only two vertices shared with the uranyl bipyramids, while the other two vertices were left non-shared. But if S1-, S3-, and S5-centered tetrahedra shared two of their vertices with two 
Ur polyhedra, S2- and S4-centered tetrahedra linked to the single bipyramid via sharing a common edge. $\mathrm{U}$ and $\mathrm{S}$ coordination polyhedra shared common vertices and edges to form wave-like infinite chains of $\left[\left(\mathrm{UO}_{2}\right)_{2}\left(\mathrm{SO}_{4}\right)_{5}\right]^{6-}$ composition (Figure 2e). Besides, the linkage of coordination polyhedra inside the chain occurred only via corner-sharing, while edge-shared sulfate tetrahedra decorated the exterior of the chain. Uranyl sulfate chains were interlinked into the pseudo layered structure via an $\mathrm{H}$-bonding system involving $\mathrm{H}_{2} \mathrm{O}$ molecules. The negative charge of the uranyl sulfate complex was compensated by six $\mathrm{Cs}^{+}$cations arranged in between the pseudo layers. It should be noted that three sites occupied by $\mathrm{H}_{2} \mathrm{O}$ molecules were localized only in the voids arranged in the plane of the chains but not between the pseudo-2D complexes.

There was one crystallographically nonequivalent $\mathrm{U}^{6+}$ atom in the structure of 4 with two short bonds $\left(<\mathrm{U} 1-\mathrm{O}_{U r}>=1.772 \AA\right.$ ) forming $\mathrm{Ur}$, which was coordinated by five oxygen atoms $<U r-\mathrm{O}_{e q}>=2.38 \AA$, belonging to sulfate tetrahedra and arranged in the equatorial plane of the pentagonal bipyramid. Two nonequivalent $\mathrm{S}^{6+}$ atoms were tetrahedrally coordinated by four $\mathrm{O}^{2-}$ atoms each. There were two types of sulfate oxyanions: $\left[\mathrm{S} \mathrm{O}_{4}\right]^{2-}$ were 2-connected, sharing two vertices with two adjacent Ur polyhedra, and $\left[\mathrm{S}_{2} \mathrm{O}_{4}\right]^{2-}$ were 3-connected (chelating-bridging), sharing vertex with one uranyl bipyramid and an edge with the neighbor one. The structure of 4 was based on the layered complexes of $\left[\left(\mathrm{UO}_{2}\right)\left(\mathrm{SO}_{4}\right)_{2}\right]^{2-}$ composition (Figure $2 \mathrm{~g}$ ), interlinked by the two non-equivalent $\mathrm{Cs}^{+}$cations.

\subsection{Topological Analysis}

The anion topology of the U-S layer in $\mathbf{1}$ (Figure $2 \mathrm{~b}$ ) was determined using the approach described in [14]. It belonged to the $5^{4} 4^{1} 3^{2}$-I topological type according to the classification suggested in [15], and it has been observed in the structures of several synthetic uranyl sulfates [16,17], chromates [18], and phosphates [19]. Topology consisted of chains of pentagons, half of which were occupied by the Ur edge-sharing dimers, separated by the groups of one square and two triangles. Each triangle corresponded to the 3-connected face of the sulfate tetrahedra, while the squares were vacant. The orientation of non-shared vertex in the structure of $\mathbf{1}$ alternated by rows (Figure 2a): in the first row, all vertices were oriented down, in the second-up, then again down, etc. Thus, the geometric isomer represented in $\mathbf{1}$ was described by the $(\mathbf{u})(\mathbf{d})$ matrix. It should be noted that the layered complex in the structure of $\mathbf{1}$ was very similar to those found in the structures of uranyl sulfate minerals as deliensite, $\mathrm{Fe}\left[\left(\mathrm{UO}_{2}\right)_{2}\left(\mathrm{SO}_{4}\right)_{2}(\mathrm{OH})_{2}\right]\left(\mathrm{H}_{2} \mathrm{O}\right)_{7}$ [20], plášlite, $\mathrm{Na}\left(\mathrm{UO}_{2}\right)\left(\mathrm{SO}_{4}\right)(\mathrm{OH}) \cdot 2 \mathrm{H}_{2} \mathrm{O}$ [21], and others [22]. But their topologies were significantly distinct due to various arrangements of the uranyl dimers within the layer. In the structure of $\mathbf{1}$, dimers were stacked in a ladder fashion, while in the structures of aforementioned minerals, dimers were arranged parallel to each other, thus forming, typical for minerals, so-called phosphuranylite topology [23]. Differences between these topological isomers have been recently described in [17].

The crystal structure of 2 [8] was based on the layered complexes of the $\left[\left(\mathrm{UO}_{2}\right)_{4}\left(\mathrm{SO}_{4}\right)_{2} \mathrm{O}_{3}(\mathrm{OH})\right]^{6-}$ composition (Figure 2c,d). Its topology was described by the $5^{2} 4^{3} 3^{2}$ ring symbol and was related to one of the most common topological types among the natural uranyl sulfates [22], the so-called zippeite topology. Topology consisted of zig-zag infinite chains of edge-sharing pentagons separated by chains of squares and triangles.

The topology of the uranyl sulfate chain in the structure of $\mathbf{3}$ (Figure 2f) could be visualized using the theory of graphical representation [24]. Double links between the black and white vertices in a graph indicate the sharing of an edge between uranyl coordination polyhedra and sulfate oxyanion. The chain topology in $\mathbf{3}$ was unprecedented for the structural chemistry of inorganic oxysalts and belonged to the novel $c c 1-2: 5-1$ type.

The graph of the uranyl sulfate layered complex in the structure of 4 belonged to the $c c 2-1: 2-21$ topological type (Figure $2 \mathrm{~h}$ ) and consisted of dense 4-membered and large 12-membered rings. This topology is rather rare but has been observed in the structures of a few actinide-bearing compounds. It has been described at first in the structure of isotypic Cs neptunyl sulfate compound [25], and later in the structures of Ba uranyl selenite [26] and organically templated uranyl sulfate [27]. 


\subsection{Structural Complexity}

The information-based complexity parameters for $\mathbf{1 - 4}$ are given in Table 5. This approach, recently developed by S.V. Krivovichev [28-30] and successfully implemented in [22,31,32], allowed to compare the structures in terms of their information content and to analyze contributions of various substructural building blocks into the complexity of the whole structure. Structural complexity is a negative contribution to the configurational entropy of a crystalline compound and thus could help to understand and describe the processes of various structures formation in the laboratory and, what is of special interest, in nature.

Table 5. Structural and topological complexity parameters for the uranyl sulfate compounds.

\begin{tabular}{|c|c|c|c|c|c|c|c|c|c|c|c|c|}
\hline \multirow{2}{*}{ Compound } & \multicolumn{4}{|c|}{$\begin{array}{c}\text { Complexity Parameters of the } \\
\text { Crystal Structure }\end{array}$} & \multicolumn{4}{|c|}{$\begin{array}{c}\text { Structural Complexity of } \\
\text { the U-S Unit }\end{array}$} & \multicolumn{4}{|c|}{$\begin{array}{c}\text { Topological Complexity of } \\
\text { the U-S Unit }\end{array}$} \\
\hline & Sp. Gr. & $v$ & $I_{G}$ & $I_{G, \text { total }}$ & $\begin{array}{l}\text { Layer/Rod } \\
\text { Gr. }\end{array}$ & $v$ & $I_{G}$ & $I_{G, t o t a l}$ & $\begin{array}{l}\text { Layer/Rod } \\
\text { Gr. }\end{array}$ & $v$ & $I_{G}$ & $I_{G, \text { total }}$ \\
\hline 1 & Pnma & 100 & 3.844 & 384.386 & $p 2_{1} / a$ & 40 & 3.322 & 132.877 & $p 2_{1} / a$ & 40 & 3.322 & 132.877 \\
\hline 2 & $P-1$ & 78 & 5.285 & 412.261 & $p-1$ & 54 & 4.755 & 256.764 & $p-1$ & 54 & 4.755 & 256.764 \\
\hline 3 & $P-1$ & 92 & 5.524 & 508.168 & $r_{-1}$ & 62 & 4.954 & 307.160 & $f_{\mathrm{a}}$ mam & 62 & 3.599 & 223.160 \\
\hline 4 & $P-1$ & 141 & 6.161 & 868.677 & $p-1$ & 54 & 4.755 & 256.764 & $p-1$ & 54 & 4.755 & 256.764 \\
\hline $\mathrm{K}_{4}\left[\mathrm{UO}_{2}\left(\mathrm{SO}_{4}\right)_{3}\right]$ & Pnma & 176 & 4.641 & 816.860 & pm & 36 & 4.337 & 156.117 & pmm2 & 36 & 3.892 & 140.117 \\
\hline Marecottite & $P 2_{1} / n$ & 60 & 3.907 & 234.413 & $p 2_{1} / a$ & 52 & 3.700 & 192.423 & $p 2_{1} / a$ & 52 & 3.700 & 192.423 \\
\hline Peligotite & $P-1$ & 82 & 5.382 & 441.319 & & & & & & & & \\
\hline Lussierite & $C_{c}$ & 104 & 5.700 & 592.846 & $p-1$ & 23 & 4.524 & 104.042 & $p m$ & 23 & 3.915 & 90.042 \\
\hline Klaprothite & $P 2_{1} / c$ & 164 & 5.382 & 882.639 & & & & & & & & \\
\hline Ottohahnite & $P-1$ & 126 & 6.000 & 768.000 & $p-1$ & 62 & 4.954 & 307.160 & $p-1$ & 62 & 4.954 & 307.160 \\
\hline
\end{tabular}

The general trend in evolution of crystallization was recently summarized as follows [33-36]: complexities of structures formed on the latter stages of crystallization are higher than those for the phases growing on the primary stages, wherein very complex structures may form as transitional architectures prior or between phases with relatively small amounts of structural information.

The evaluation was performed in several steps (Figure 3). First, the topological complexity (TI), according to the maximal rod (for chains) or layer symmetry group, was calculated since these are the basic structural units. Second, the structural complexity (SI) of the units was analyzed, taking into account its real symmetry. The next contribution to information came from the stacking (LS) of chained and layered complexes (if more than one layer or chain is in the unit cell). The fourth contribution to the total structural complexity was given by the interstitial structure (IS). And the last portion of information came from the interstitial $\mathrm{H}$ bonding system $(\mathbf{H})$. It should be noted that the $\mathrm{H}$ atoms related to the U-bearing chains and layers were considered as a part of those complexes, but not within the contribution of the $\mathbf{H}$-bonding system. For instance, contribution of $\mathbf{H}$ was equal to the difference between complexity parameters for the whole structure and those for the structural model with no $\mathrm{H}$ atoms; contribution of IS was equal to the difference between complexity parameters for the structural model with no $\mathrm{H}$ atoms and those for the structural model with no interstitial substructure at all; etc. Complexity parameters for the aforementioned contributions were calculated manually using the general formulae [28-30]. Complexity parameters for the whole structures were calculated using the ToposPro package [37]. Complexity calculations showed that the crystal structures of $\mathbf{1}, \mathbf{2}$, and $\mathbf{4}$ should be described as intermediate, possessing the values below 500 bits/cell, while compound 3 just slightly passed through this border (508.168 bits/cell) and should be described as complex. 

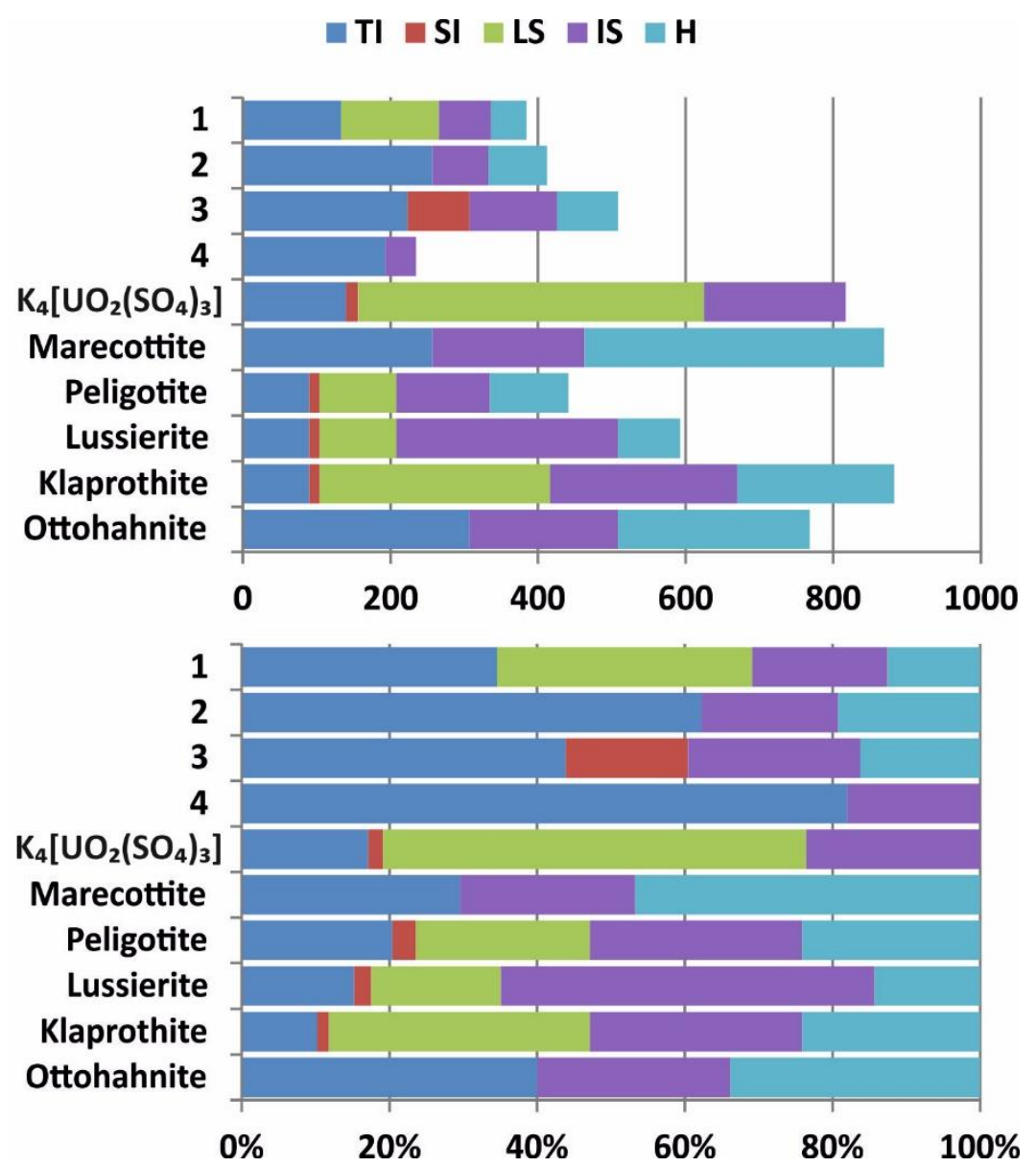

Figure 3. Ladder diagrams showing contributions and normalized contributions (in \%) of various factors to structural complexity in terms of bits per unit cell. Legend: TI = topological information; $\mathrm{CI}=$ cluster information; $\mathrm{SI}=$ structural information; $\mathrm{LS}=$ layer stacking; $\mathrm{IS}$ = interstitial structure; $\mathrm{HB}=$ hydrogen bonding. See Table 5 and text for details.

\section{Discussion}

The crystals of 1-4 could be distributed over two genetically distinct groups. The crystals of 1 and $\mathbf{2}$ were formed during the first stage of synthetic schoepite alteration. Their structures were based on the layered complexes with the edge-sharing linkage of uranyl pentagonal bipyramids, which reflected the heating of the reaction solution during the growth processes. It should be noted that original schoepite was obtained from nearly neutral solutions, whereas the aqueous medium in our experiment was significantly more acidic $(\mathrm{pH} \sim 2)$. Acidic conditions and the presence of additional $\mathrm{Cs}^{+}$cations destroyed the dense layer in the structure of schoepite, but high temperature allowed preserving an edge-sharing complexation of $U r$ coordination polyhedra. An initial solution in the experiment contained the Cs:U:S molar ratio 1:1:1, which explained the predominance of the $\mathrm{Cs}\left[\left(\mathrm{UO}_{2}\right)\left(\mathrm{SO}_{4}\right)(\mathrm{OH})\right]\left(\mathrm{H}_{2} \mathrm{O}\right)_{0.25}(\mathbf{1})$ phase in the precipitate. The lower amount of crystals of 2 could be explained by the lower temperature of the experiment that is preferable for the formation of the zippeite-type structures.

The crystals of 3 and 4 could be attributed to the later genetic type because they were grown after cooling the system at room temperature conditions. It is of interest that both phases had in their structures uranyl pentagonal bipyramids that shared an edge with the sulfate tetrahedra. Similar arrangement of $U r$ and sulfate oxyanions were found in the structures of four natural uranyl sulfates: klaprothite, $\mathrm{Na}_{6}\left(\mathrm{UO}_{2}\right)\left(\mathrm{SO}_{4}\right)_{4}\left(\mathrm{H}_{2} \mathrm{O}\right)_{4}$, its polymorph peligotite, $\mathrm{Na}_{6}\left(\mathrm{UO}_{2}\right)\left(\mathrm{SO}_{4}\right)_{4}\left(\mathrm{H}_{2} \mathrm{O}\right)_{4}$, ottohahnite, $\mathrm{Na}_{6}\left(\mathrm{UO}_{2}\right)_{2}\left(\mathrm{SO}_{4}\right)_{5}\left(\mathrm{H}_{2} \mathrm{O}\right)_{8.5}$ [38], and lussierite $\mathrm{Na}_{10}\left[\left(\mathrm{UO}_{2}\right)\left(\mathrm{SO}_{4}\right)_{4}\right]\left(\mathrm{SO}_{4}\right)_{2} \cdot 3 \mathrm{H}_{2} \mathrm{O}$ [39]. The same clusters 
that were observed in the structures of klaprothite and peligotite (Figure 4 ) were previously described in a few synthetic compounds [40-43], which were grown using low temperature $\left(70{ }^{\circ} \mathrm{C}\right)$ hydrothermal experiments. The presence of such unusual arrangements of edge-sharing uranyl bipyramid and sulfate tetrahedra have never been observed during regular evaporation experiments at room temperature. Thus, we could assume that these clusters were formed on the first, hydrothermal stage of our experiment. Moreover, the presence of such S-enriched $\left[\left(\mathrm{UO}_{2}\right)\left(\mathrm{SO}_{4}\right)_{4}\right]^{6-}$ clusters in the heated solution could explain the local disturbance of the Cs:U:S 1:1:1 concentration, which induced the formation of S-"depleted" zippeite-like compound 2. There is one more known synthetic K-bearing uranyl sulfate, whose structure is based on the double klaprothite-type clusters [44]. This row could be continued by the further doubling of the cluster in $\mathrm{K}_{4}\left(\mathrm{UO}_{2}\left(\mathrm{SO}_{4}\right)_{3}\right)$ [44] to get the quadruple $0 \mathrm{D}$ unit in the structure of ottohahnite (Figure 4). Further increase of the cluster size led to the arrangement of the infinite chains in the structure of 3, which in turn, during the dehydration process [34], would transform into the layer in the structure of 4 . The absence of the structures based on the 0D structural units in our experiment might come from the requirements for longer storage at elevated, but not high, temperatures, and higher concentrations of $\mathrm{Cs}^{+}$cations and $\left[\mathrm{SO}_{4}\right]^{2-}$ oxyanions in the initial solution.

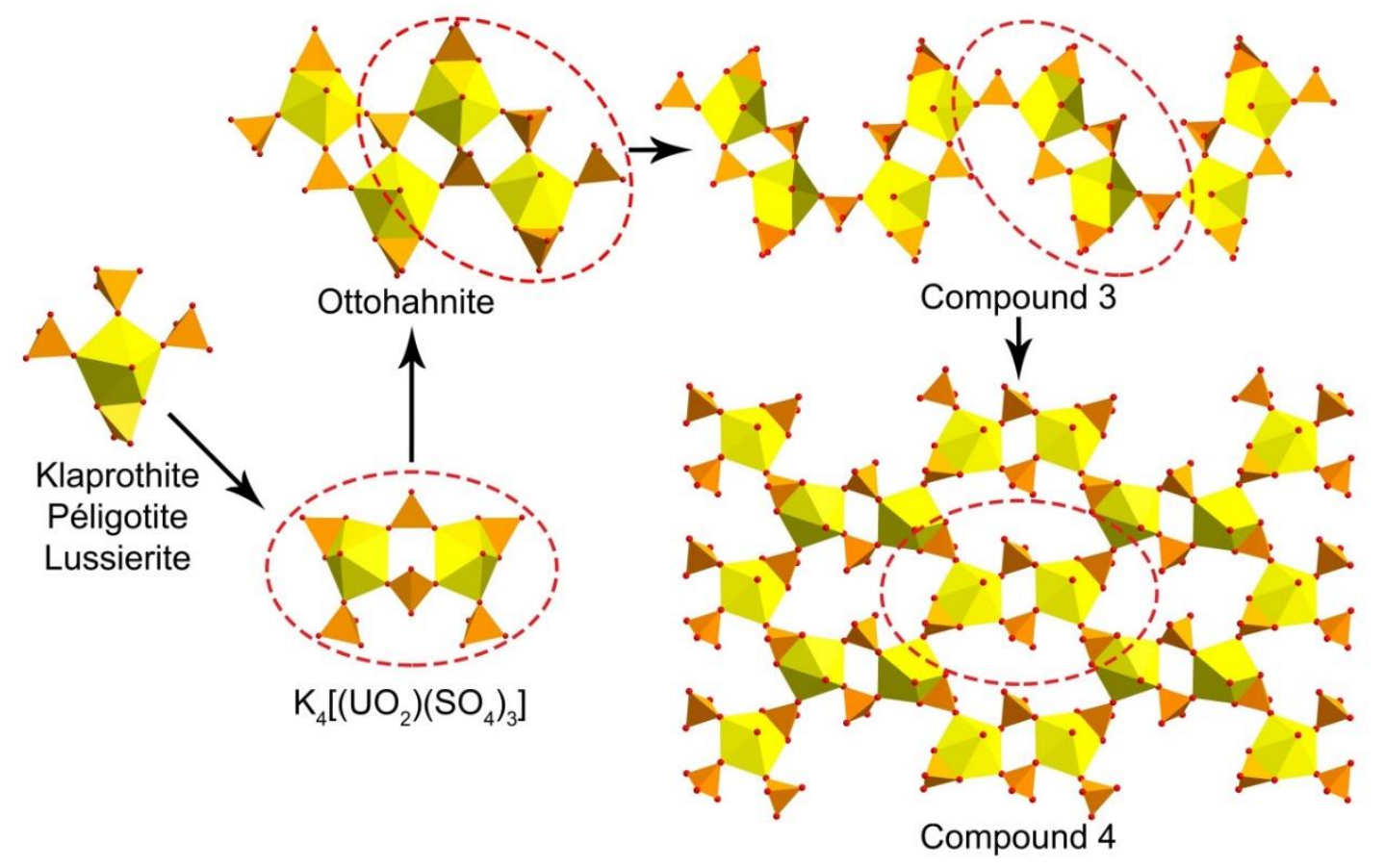

Figure 4. Scheme of structural evolution for the 1D and 2D uranyl sulfate complexes, which have an edge-sharing uranyl bipyramid and sulfate tetrahedron.

\section{Conclusions}

Summarizing our crystal's chemical observations, we could suggest that the majority of the discovered natural uranyl sulfates were grown from heated solutions, and the temperature range could be assumed from the manner of interpolyhedral linkage. The presence of edge-sharing uranyl bipyramids (phosphuranylite anion topology [22]), most likely pointed to the temperatures of higher than $100{ }^{\circ} \mathrm{C}$, and the crystal growth should apparently occur directly in hydrothermal conditions. The linkage of sulfate tetrahedra with $U r$ through the common edges also involved elevated temperatures, but of less values $\left(\sim 70-100^{\circ} \mathrm{C}\right)$, which could be achieved by cooling the system. Moreover, in the second case, crystallization might start much later at environmental conditions but from the initially heated solutions. The enriched solution might pass some way along the cracks in the bedrock, transferring klaprothite-like clusters in the dissolved form. It is of interest that complexity parameters of the synthetic compounds were generally lower than that of minerals, whose structures 
were based on the complexes with the same or genetically similar topologies. Furthermore, the topological complexity of the uranyl sulfate structural units contributed the major portion to the overall complexity of the synthesized compounds, while the complexity of the respective minerals was largely governed by the interstitial structure and H-bonding system.

Supplementary Materials: The following are available online at http://www.mdpi.com/2073-4352/9/12/660/s1: Cif files for 1,3, and 4 .

Author Contributions: Conceptualization, O.S.T. and V.V.G.; Methodology, O.S.T. and I.V.K.; Investigation, O.S.T., I.V.K., S.N.B., and A.A.Z.; Writing-Original Draft Preparation, O.S.T. and V.V.G.; Writing-Review and Editing, V.V.G.; Visualization, V.V.G. and I.V.K.

Funding: This research was funded by the Russian Science Foundation (grant 18-17-00018).

Acknowledgments: The XRD and EDX measurements have been performed at the X-ray Diffraction Center and Center for Microscopy and Microanalysis of the St. Petersburg State University.

Conflicts of Interest: The authors declare no conflict of interest.

\section{References}

1. Finch, R.J.; Ewing, R.C. The corrosion of uraninite under oxidizing conditions. J. Nucl. Mater. 1992, 190, $133-156$.

2. Finch, R.J.; Murakami, T. Systematics and paragenesis of uranium minerals. In Uranium: Mineralogy, Geochemistry and the Environment; Burns, P.C., Ewing, R.C., Eds. Rev. Mineral. Geochem. 1999, 38, 91-179.

3. Plášil, J. Oxidation-hydration weathering of uraninite: The current state-of-knowledge. J. Geosci. 2014, 59, 99-114.

4. Krivovichev, S.V.; Plášil, J. Mineralogy and crystallography of uranium. In Uranium: From Cradle to Grave; Burns, P.C., Sigmon, G.E., Eds. MAC Short Courses 2013, 43, 15-119.

5. Plášil, J. Uranyl-oxide hydroxy-hydrate minerals: Their structural complexity and evolution trends. Eur. J. Mineral. 2018, 30, 237-251.

6. Walker, T.L. Schoepite, a new uranium mineral from Kasolo, Belgian Congo. Amer. Miner. 1923, 8, 67-69.

7. Plášil, J. The crystal structure of uranyl-oxide mineral schoepite, $\left[\left(\mathrm{UO}_{2}\right)_{4} \mathrm{O}(\mathrm{OH})_{6}\right]\left(\mathrm{H}_{2} \mathrm{O}\right)_{6}$, revisited. J. Geosci. 2018, 63, 65-73.

8. Serezhkina, L.B.; Grigor'ev, M.S.; Makarov, A.S.; Serezhkin, V.N. Synthesis and Structure of Cesium-Containing Zippeite. Radiochemistry 2015, 57, $20-25$.

9. Nipruk, O.V.; Knyazev, A.V.; Chernorukov, G.N.; Pykhova, Y.P. Synthesis and study of hydrated uranium(VI) oxides, $\mathrm{UO}_{3} \cdot n \mathrm{H}_{2} \mathrm{O}$. Radiochemistry 2011, 53, 146-150.

10. CrysAlisPro Software System, version 1.171.38.46; Rigaku Oxford Diffraction: Oxford, UK, 2015.

11. Sheldrick, G.M. SHELXT-Integrated space-group and crystal structure determination. Acta Crystallogr. 2015, A71, 3-8.

12. Sheldrick, G.M. Crystal structure refinement with SHELXL. Acta Crystallogr. 2015, C71, 3-8.

13. Dolomanov, O.V.; Bourhis, L.J.; Gildea, R.J.; Howard, J.A.K.; Puschmann, H. OLEX2: A complete structure solution, refinement and analysis program. J. Appl. Cryst. 2009, 42, 339-341.

14. Burns, P.C.; Miller, M.L.; Ewing, R.C. $\mathrm{U}^{6+}$ minerals and inorganic phases: A comparison and hierarchy of structures. Can. Mineral. 1996, 34, 845-880.

15. Krivovichev, S.V. Structural Crystallography of Inorganic Oxysalts; Oxford University Press: Oxford, UK, 2008.

16. Grechishnikova, E.V.; Virovets, A.V.; Peresypkina, E.V.; Serezhkina, L.B. Synthesis and crystal structure of the $\left(\mathrm{C}_{2} \mathrm{~N}_{4} \mathrm{H}_{7} \mathrm{O}\right)\left[\mathrm{UO}_{2}\left(\mathrm{SO}_{4}\right)(\mathrm{OH})\right] \cdot 0.5 \mathrm{H}_{2} \mathrm{O}$. Zh. Neorg. Khim. (Russ.) 2005, 50, 1800-1805.

17. Nazarchuk, E.V.; Charkin, D.O.; Siidra, O.I.; Gurzhiy, V.V. Synthesis and Crystal Structures of New Layered Uranyl Compounds Containing Dimers $\left[\left(\mathrm{UO}_{2}\right)_{2} \mathrm{O}_{8}\right]$ of Edge-Linked Pentagonal Bipyramids. Radiochemistry 2018, 60, 498-506.

18. Unruh, D.K.; Baranay, M.; Pressprich, L.; Stoffer, M.; Burns, P.C. Synthesis and characterization of uranyl chromate sheet compounds containing edge-sharing dimers of uranyl pentagonal bipyramids. J. Solid State Chem. 2012, 186, 158-164. 
19. Ok, K.M.; Baek, J.; Halasyamani, P.S.; O’Hare, D. New Layered Uranium Phosphate Fluorides: Syntheses, Structures, Characterizations, and Ion-Exchange Properties of $A\left(\mathrm{UO}_{2}\right) \mathrm{F}\left(\mathrm{HPO}_{4}\right) \cdot x \mathrm{H}_{2} \mathrm{O}\left(A=\mathrm{Cs}^{+}, \mathrm{Rb}^{+}, \mathrm{K}^{+}\right.$; $x=0-1)$. Inorg. Chem. 2006, 45, 10207-10214.

20. Plášil, J.; Hauser, J.; Petříček, V.; Meisser, N.; Mills, S.J.; Škoda, R.; Fejfarová, K.; Čejka, J.; Sejkora, J.; Hloušek, J.; et al. Crystal structure and formula revision of deliensite, $\mathrm{Fe}\left[\left(\mathrm{UO}_{2}\right)_{2}\left(\mathrm{SO}_{4}\right)_{2}(\mathrm{OH})_{2}\right]\left(\mathrm{H}_{2} \mathrm{O}\right)_{7}$. Mineral. Mag. 2012, 76, 2837-2860.

21. Kampf, A.R.; Kasatkin, A.V.; Čejka, J.; Marty, J. Plášilite, $\mathrm{Na}\left(\mathrm{UO}_{2}\right)\left(\mathrm{SO}_{4}\right)(\mathrm{OH}) \cdot 2 \mathrm{H}_{2} \mathrm{O}$, a new uranyl sulfate mineral from the Blue Lizard mine, San Juan County, Utah, USA. J. Geosci. 2015, 60, 1-10.

22. Gurzhiy, V.V.; Plášil, J. Structural complexity of natural uranyl sulfates. Acta Crystallogr. 2019, B75, 39-48.

23. Demartin, F.; Diella, V.; Donzelli, S.; Gramaccioli, C.M.; Pilati, T. The importance of accurate crystal structure determination of uranium minerals. I. Phosphuranylite $\mathrm{KCa}\left(\mathrm{H}_{3} \mathrm{O}\right)_{3}\left(\mathrm{UO}_{2}\right)_{7}\left(\mathrm{PO}_{4}\right)_{4} \mathrm{O}_{4} \cdot 8 \mathrm{H}_{2} \mathrm{O}$. Acta Crystallogr. 1991, B47, 439-446.

24. Krivovichev, S.V. Combinatorial topology of salts of inorganic oxoacids: Zero-, one- and two-dimensional units with corner-sharing between coordination polyhedra. Crystallogr. Rev. 2004, 10, 185-232.

25. Fedoseev, A.M.; Budantseva, N.A.; Grigor'ev, M.S.; Bessonov, A.A.; Astafurova, L.N.; Lapitskaya, T.S.; Krupa, J.C. Sulfate Compounds of Hexavalent Neptunium and Plutonium. Radiochim. Acta 1999, 86, 17-22.

26. Almond, P.M.; Peper, S.; Bakker, E.; Albrecht-Schmitt, T.E. Variable Dimensionality and New Uranium Oxide Topologies in the Alkaline-Earth Metal Uranyl Selenites $A E\left[\left(\mathrm{UO}_{2}\right)\left(\mathrm{SeO}_{3}\right)_{2}\right](A E=\mathrm{Ca}, \mathrm{Ba})$ and $\mathrm{Sr}\left[\left(\mathrm{UO}_{2}\right)\left(\mathrm{SeO}_{3}\right)_{2}\right]$ - $2 \mathrm{H}_{2}$ O. J. Solid State Chem. 2002, 168, 358-366.

27. Norquist, A.J.; Doran, M.B.; O'Hare, D. The effects of linear diamine chain length in uranium sulfates. Solid State Sci. 2003, 5, 1149-1158.

28. Krivovichev, S.V. Topological complexity of crystal structures: Quantitative approach. Acta Crystallogr. A 2012, 68, 393-398.

29. Krivovichev, S.V. Structural complexity and configurational entropy of crystalline solids. Acta Crystallogr. B 2016, 72, 274-276.

30. Krivovichev, S.V. Ladders of information: What contributes to the structural complexity in inorganic crystals. Z. Kristallogr. 2018, 233, 155-161.

31. Krivovichev, V.G.; Krivovichev, S.V.; Charykova, M.V. Selenium Minerals: Structural and Chemical Diversity and Complexity. Minerals 2019, 9, 455.

32. Gurzhiy, V.V.; Kuporev, I.V.; Kovrugin, V.M.; Murashko, M.N.; Kasatkin, A.V.; Plášil, J. Crystal Chemistry and Structural Complexity of Natural and Synthetic Uranyl Selenites. Crystals 2019, 9, 639.

33. Gurzhiy, V.V.; Tyumentseva, O.S.; Krivovichev, S.V.; Krivovichev, V.G.; Tananaev, I.G. Mixed uranyl sulfate-selenates: variable composition and crystal structures. Cryst. Growth Des. 2016, 16, 4482-4492.

34. Gurzhiy, V.V.; Krivovichev, S.V.; Tananaev, I.G. Dehydration-driven evolution of topological complexity in ethylamonium uranyl selenates. J. Solid State Chem. 2017, 247, 105-112.

35. Gurzhiy, V.V.; Tyumentseva, O.S.; Britvin, S.N.; Krivovichev, S.V.; Tananaev, I.G. Ring opening of azetidine cycle: First examples of 1-azetidinepropanamine molecules as a template in hybrid organic-inorganic compounds. J. Molec. Struct. 2018, 1151, 88-96.

36. Gurzhiy, V.V.; Tyumentseva, O.S.; Izatulina, A.R.; Krivovichev, S.V.; Tananaev, I.G. Chemically Induced Polytypic Phase Transitions in the $\mathrm{Mg}\left[\left(\mathrm{UO}_{2}\right)\left(\mathrm{TO}_{4}\right)_{2}\left(\mathrm{H}_{2} \mathrm{O}\right)\right]\left(\mathrm{H}_{2} \mathrm{O}\right)_{4}(T=\mathrm{S}$, Se) System. Inorg. Chem. 2019, 58, 14760-14768.

37. Blatov, V.A.; Shevchenko, A.P.; Proserpio, D.M. Applied topological analysis of crystal structures with the program package ToposPro. Cryst. Growth Des. 2014, 14, 3576-3586.

38. Kampf, A.R.; Plášil, J.; Kasatkin, A.V.; Marty, J.; Čejka, J. Klaprothite, péligotite and ottohahnite, three new minerals with bidentate $\mathrm{UO}_{7}-\mathrm{SO}_{4}$ linkages from the Blue Lizard mine, San Juan County, Utah, USA. Miner. Mag. 2017, 81, 753-779.

39. Kampf, A.R.; Olds, T.A.; Plášil, J.; Nash, B.P.; Marty, J. Lussierite, a new sodium uranyl sulfate mineral with bidentate $\mathrm{UO}_{7}-\mathrm{SO}_{4}$ linkage from the Blue Lizard mine, San Juan County, Utah, USA. Miner. Mag. 2019, 1-25. [CrossRef]

40. Plášil, J.; Meisser, N.; Čejka, J. The crystal structure of $\mathrm{Na}_{6}\left[\left(\mathrm{UO}_{2}\right)\left(\mathrm{SO}_{4}\right)_{4}\right]\left(\mathrm{H}_{2} \mathrm{O}\right)_{4}$ : X-ray and Raman spectroscopy study. Canad. Miner. 2015, 54, 5-20.

41. Burns, P.C.; Hayden, L.A. A uranyl sulfate cluster in $\mathrm{Na}_{10}\left[\left(\mathrm{UO}_{2}\right)\left(\mathrm{SO}_{4}\right)_{4}\right]\left(\mathrm{SO}_{4}\right)_{2} \cdot 3 \mathrm{H}_{2} \mathrm{O}$. Acta Crystallogr. C 2002, 58, i121-i123. 
42. Hayden, L.A.; Burns, P.C. The sharing of an edge between a uranyl pentagonal bipyramid and sulfate tetrahedron in the structure of $\mathrm{KNa}_{5}\left[\left(\mathrm{UO}_{2}\right)\left(\mathrm{SO}_{4}\right)_{4}\right]\left(\mathrm{H}_{2} \mathrm{O}\right)$. Canad. Miner. 2002, 40, 211-216.

43. Hayden, L.A.; Burns, P.C. A novel uranyl sulfate cluster in the structure of $\mathrm{Na}_{6}\left(\mathrm{UO}_{2}\right)\left(\mathrm{SO}_{4}\right)_{4}\left(\mathrm{H}_{2} \mathrm{O}\right)_{2}$. J. Solid State Chem. 2002, 163, 313-318.

44. Mikhailov, Y.N.; Kokh, L.A.; Kuznetsov, V.G.; Grevtseva, T.G.; Sokol, S.K.; Ellert, G.V. Synthesis and crystal structure of potassium trisulfatouranylate $\mathrm{K}_{4}\left(\mathrm{UO}_{2}\left(\mathrm{SO}_{4}\right)_{3}\right.$. Koord. Khimiya 1977, 3, 500-513. (In Russian)

(C) 2019 by the authors. Licensee MDPI, Basel, Switzerland. This article is an open access article distributed under the terms and conditions of the Creative Commons Attribution (CC BY) license (http://creativecommons.org/licenses/by/4.0/). 